\title{
ROAD MAP OF RURAL TOURISM DEVELOPMENT IN RAYHOROD UNITED TERRITORIAL COMMUNITY
}

\author{
Nataliya MATVIIENKO*, Volodymyr MATVIIENKO, Svitlana MICHENKO
}

\author{
Taras Shevchenko National University of Kyiv, Ukraine
}

*rika11@ukr.net

\begin{abstract}
The National Tourism Organization of Ukraine has declared 2020 the year of rural (green) tourism. This is not accidental decision, because Rural Development and Tourism was proclaimed by the UNWTO General Assembly as the theme of World Tourism Day 2020. The Ukrainian village is going through difficult times. More than 500 villages have disappeared from the map of our country since 1991, and almost 5,000 are now on the verge of extinction. In many countries around the world, rural tourism is an integral part of integrated socio-economic development programs of united territorial communities. The article proposes a road map for the development of rural green tourism for the center of Rayhorod united territorial community (located in the Haisyn district, Vinnytsia oblast) - the village of Rayhorod. The methodological basis of the study was a road map for the development of tourism in the united territorial communities elaborated by the NGO "Ukrainian Union of Rural Green Tourism". The information base of the research was the data obtained during the expeditionary research in the community. Monitoring the potential of the territory and assessing the readiness of the community for sustainable tourism development was completed by developing a SWOT analysis. It is determined that the studied community has all the prerequisites for the development of this type of tourism. A big problem is the lack of basic knowledge of rural residents about the opportunities and benefits of tourism development for rural areas. It is substantiated that the organization of festivals can become a "tourist magnet" of the village. The community already has some experience, as it annually holds a festival dedicated to the Village Day, which is becoming more and more popular every year. A trip on the historic railway, which is very popular tourist activity in Europe, could be a "tourist highlight" of Rayhorod community. The visitors may be attracted by the picturesque Podolian landscapes that open from the windows of the train running in the valley of the southern Bug. Establishing cooperation with the territorial communities of the region in the direction of joint activities for the development of rural green tourism is one of the goals of the long-term Tourism Development Program in Vinnytsia oblast for 2021-2027; the article determines the need to elaborate a separate coupled program for the development of rural tourism for the village of Rayhorod.
\end{abstract}

Key words: road map, rural green tourism, community, Rural Green Tourism Union.

DOI: https://doi.org/10.17721/2413-7154/2021.86.16-29

UDC: $338: 48$

Received: August 19, 2021.

Revised: October 22, 2021.

Accepted: October 29, 2021.

\section{ДОРОЖНЯ КАРТА РОЗВИТКУ СІЛЬСЬКОГО ТУРИЗМУ В РАЙГОРОДСЬКІЙ ОБ'ЄДНАНІЙ ТЕРИТОРІАЛЬНІЙ ГРОМАДІ}

\author{
Наталія МАТВІєНКО*, Володимир МАТВІєНКО, Світлана МІЧЕНКО
}

Київський національний університет імені Івана Франка, Україна *rika11@ukr.net

\begin{abstract}
Анотація: Національною туристичною організацією України 2020 рік було оголошено роком сільського (зеленого) туризму. І це не випадково, адже саме «Сільський розвиток і туризм» було проголошено Генеральною Асамблеєю ЮНВТО темою Всесвітнього дня туризму 2020 року. Українське село переживає складні часи. 31991 року 3 мапи нашої держави зникло понад 500 сіл. У багатьох країнах світу сільський туризм $\epsilon$ невід'ємною складовою частиною програм комплексного соціально-економічного розвитку об'єднаних територіальних громад. У статті запропоновано дорожню карту розвитку сільського зеленого туризму для центра Райгородської ОТГ Гайсинського району Вінницької області - села Райгород. Методологічною базою дослідження слугували розробки дорожньої карти розвитку туризму в ОТГ громадської організації Спілки сільського зеленого туризму України. Інформаційною базою дослідження стали дані отримані під час експедиційного дослідження на території громади. Проведення моніторингу потенціалу території та оцінки готовності громади до сталого розвитку туризму було завершено розробкою SWOT-аналізу. Обґрунтовано, що «туристичним магнітом» даного села може стати організація фестивалів, або подорож історичною залізницею. Визначено за необхідність складення окремої Програми розвитку сільського туризму для Райгородської сільської ради.
\end{abstract}

Ключові слова: дорожня карта, сільський зелений туризм, громада, Спілка сільського зеленого туризму. 
Актуальністьдослідження. Експерти ЮНВТО притримуються думки, що розвиток сільського туризму це не тільки диверсифікація туристичного сектору, а й засіб стимулювання розвитку сільських територій. У 2019 році відбувся саміт ЮНВТО «Технології розвитку сільських територій», де розглядалося питання реагування туризму на виклики 3 якими стикаються сільські території в процесі свого розвитку. Саме «Сільський розвиток i туризм» було проголошено Генеральною Асамблеєю ЮНВТО темою Всесвітнього дня туризму 2020 року. Національна туристична організація України також оголосила 2020 рік роком сільського (зеленого) туризму.

Українське село переживає складні часи. 3 1991 року з мапи нашої держави зникло понад 500 сіл та майже п'ять тисяч нині перебувають на межі вимирання. За таких темпів сільська поселенська структура України за декілька десятиліть може зменшитися на 17\% (Vihrov, 2018). Розвиток сільського туризму може стати одним з інструментів для порятунку сільських населених пунктів від зникнення, оскільки виступає не окремим явищем, а частиною розвитку села. У багатьох країнах світу сільський туризм $є$ невід'ємною складовою частиною програм комплексного соціально-економічного розвитку об'єднаних територіальних громад (ОТГ). Саме тому актуальним є дослідження можливих шляхів розвитку сільського туризму в ОТГ України.

Аналіз останніх досліджень та публікацій. Питанням теорії та практики організації та функціонування сільського туризму, перспективності та пріоритетності його розвитку в Україні присвячено ряд праць українських вчених та практиків (Gaponenko et al., 2019; Gorishevsky et al., 2003; Kudla, 2005; Luzhanskaya et al., 2008; Rutinsky \& Zinko, 2008). Окрему працю присвячено дослідженню організації підприємницької діяльності в сфері сільського туризму особами 3 інвалідністю (Barna et al., 2019). При дослідженні джерел щодо дорожньої карти для розвитку в ОТГ туризму загалом, ми звернули увагу на розробки саме практиків. Кроки, які націлені на розвиток туризму у громадах, запропонував керівник туристичноінформаційного центру «Турінформ Закарпаття», засновник онлайн-платформи «Школа сільського туризму» Олександр Коваль (Koval, 2019):

\section{1. Крок}

- Створити ініціативну групу (команду);

- Залучити волонтерів (громадських організації, шкіл, клубів);

- Розпочати відкритий діалог у громаді.

2. Крок

- Оцінити ресурси території;

- Визначити перспективи залучення туристів;

- Оцінити сезонність;

- Вивчити питання щодо можливості збільшення кількості туристів.
3. Крок

- Визначити мету.

4. Крок

- Створити план дій на рік;

- Провести аудит ресурсів громади;

- Створити сайт та позиціонувати туристичну привабливість громади;

5. Крок

- Реалізувати план.

Керівник благодійного фонду «Нікополь туристичний» Олег Фельдман вважає туризм драйвером розвитку об'єднаних територіальних громад та виділяє перші кроки щодо його розвитку (Feldman, 2018):

1. Інвентаризація туристичних принад, пам'яток, інфраструктури. Партнерство 3 бізнесом. План покращення;

2. Створення разом з сусідніми ОТГ туристичних продуктів;

3. Презентація ринку: туроператорам, агенціям, іншим партнерам;

4. Партнерство з туроператорами, турагенціями.

Запропонувала свою дорожню карту розвитку туризму в ОТГ й громадська організація «Спілка сільського зеленого туризму України». Вона пропонує конкретні кроки, як розпочати довгострокову туристичну діяльність, яка не шкодить навколишньому середовищу, допомагає зберегти культурну спадщину та традиції регіону, сприяе економічному зростанню і підвищує рівень життя в ОТГ (Ukrainian Union of Rural Green Tourism, 2021).

1. Крок: Потенціал. Проведення моніторингу потенціалу територій та оцінка готовності громади до сталого розвитку туризму;

2. Крок: Право. Проведення аналізу нормативноправових актів, які регулюють діяльність у галузі туризму та його різновидів;

3. Крок: Вигоди. Оцінка суспільних вигод від туристичної діяльності;

4.Крок:Дія. Розроблення стратегіїтаопераційних заходів з розвитку сталого туризму;

5. Крок: Фінанси. Визначення джерел фінансування та підтримки розвитку туризму;

6. Крок: Знання. Підвищення кваліфікації та рівня знань;

7. Крок: Бренд. Створення бренду громади, поліпшення інфраструктури, розроблення туристичних продуктів, формування маркетингової політики;

8. Крок: Партнерство. Визначено можливості для партнерства та співробітництва.

Варто зауважити, що запропоновані Спілкою кроки $€$ гнучким інструментом, який можна використовувати відповідно до умов та реальності кожної окремої громади.

Мета дослідження. Ураховуючи вищесказане, а також те, що більшість грунтовних досліджень розвитку сільського туризму присвячено західним регіонам України, метою нашого дослідження 
визначено розробити конкретну дорожню карту розвитку сільського зеленого туризму для центра Райгородської ОТГ Гайсинського району Вінницької області - села Райгород.

Методика та методологія. Дослідження проходило у три етапи: 1) підготовка дослідження (визначення актуальності); 2) збір первинної інформації (статистичний метод, метод аналізу наукових джерел (монографічних, періодичних, картографічних, матеріалів комп'ютерної мережі Інтернет), історико-географічний, метод соціологічного опитування; 3) обробка інформації (порівняльний, статистичний, графічний, метод систематизації); 4) аналіз отриманої інформації (інтерпретація результатів, формулювання загальних висновків).

Результати дослідження. Перед початком дослідження ми провели опитування серед жителів Райгородської ОТГ та уродженців, які наразі не проживають на території громади. Опитування було розміщено на сторінці об'єднаної територіальної громади у Фейсбуці, попередньо узгоджене з головою ОТГ. В опитуванні взяли участь 115 респондентів. Метою нашого опитування було дізнатися чи $є$ бажання у місцевих мешканців досліджуваної громади започаткувати власну справу у сфері сільського туризму. За результатами опитування ми визначили, що частка мешканців громади, які хотіли б займатися розвитком сільського зеленого туризму складає 27\% (рис. 1), що на наш погляд, є досить високим показником.

Для розробки конкретної дорожньої карти розвитку сільського зеленого туризму в селі Райгород, скористаємося методичними рекомендаціями Спілки сільського зеленого туризму України.

Крок 1. (Потенціал). На першому кроці рекомендується провести моніторинг потенціалу громади та його центру - села Райгород.

У кінці 2016 року було сформовано Райгородську ОТГ Немирівського району Вінницької області. Вона включала 4 сільські ради (11 сіл), Райгородську, Семенську, Новообиходівську та Коржівську. А вже станом на 01.01.2021 року в результаті об'єднання 10 сільських рад утворилася Райгородська сільська територіальна громада в особі Райгородської сільської ради 3 центром в селі Райгород. У зв'язку з укрупненням районів Райгородську ОТГ віднесено до Гайсинського району Вінницької області. Тепер громада налічує 19 сіл та одне смт з загальною кількістю населення 7172 осіб та площею 292,4 км².

Природно-рекреаційні ресурси. Для початку зазначимо, що для розвитку сільського туризму велике значення має екологічний стан території. Стан навколишнього середовища Райгородської ОТГ можна охарактеризувати як задовільний.

Територія досліджуваної ОТГ знаходиться у межах Подільської височини лісостепової зони України. Вона пересічена ярами, балками i долинами. Клімат помірно континентальний, якому характерні тривале, нежарке літо 3 достатньою кількістю вологи та порівняно коротка м'яка зима. Середні амплітуди коливань температури протягом року не перевищують $25^{\circ} \mathrm{C}$. Також варто зазначити, що такий клімат сприятливий для сільськогосподарського виробництва, зокрема для вирощування зернових, технічних та садових культур. Для території області практично відсутні негативні гідрометеорологічні явища. Одним 3 основних видів рекреаційної діяльності влітку $\epsilon$ купально-пляжний відпочинок. Тривалість купально-пляжного періоду коливається від 95 до 110 днів, що відповідає оптимальним для рекреаційних цілей параметрам цього показника. У кліматичному відношенні Вінницька область належить до областей із найсприятливішим співвідношенням тепла і вологи, що звичайно сприяє розвитку різних видів рекреаційної діяльності. Загалом для відпочинку більш комфортним $\epsilon$ весняно-літній період, але при бажанні сільським туризмом можна займатися цілорічно.

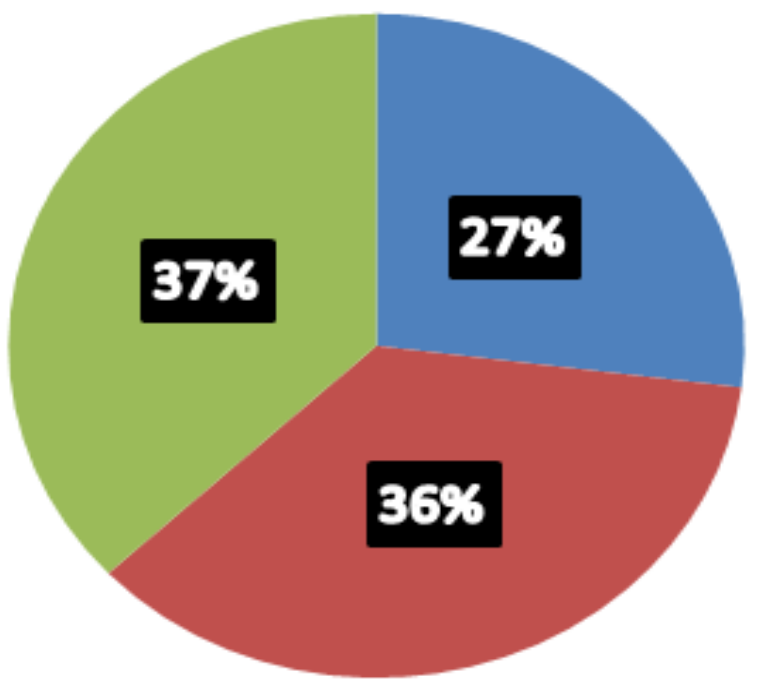

так

ні

важко

відповісти

Рис. 1. Частка населення Райгородської сільської ради, які хотіли б започаткувати власну справу в сфері сільського зеленого туризму (за результатами опитування) 
Водним об'єктам в організації відпочинку належить особлива роль. Важливим ресурсом досліджуваної території $є$ річка Південний Буг. За 30 км від села Райгород знаходиться найбільше за площею водного дзеркала (20,80 га) водосховище на Південному Бузі - Ладижинське, яке $є$ рекреаційною зоною загальнодержавного значення. Переважно на лівому березі знаходиться низка туристичних баз, спортивних комплексів, дитячих таборів та водних станцій. За кількістю ставків Вінницька область має один з найвищих показників в Україні, чому сприяє горбистий рельєф. Площа ставків в ОТГ складає близько 25 га. Власниками 4 найбільших ставків є місцеві підприємці, також три ставки не зареєстровані, створені рибалками-любителями.

Слід зазначити, що на Південному Бузі у межах Українського кристалічного щита, спостерігаються виходи гранітних порідна поверхню у вигляді порогів, що надають річці своєрідної краси. У народі ці місця називають «Швейцаріями». I хоч на території громади немає таких відомих каскадів порогів, як Губницькі, Печерські чи Мигійські (останні серед туристів вже відомі далеко за межами України), але $є$ теж дуже мальовничі та своєрідні місця і ще за часів бувшого СРСР саме село Райгород часто було останнім пунктом водних походів на байдарках, скільки тут є як залізничне, так і автомобільне сполучення. Краса місцевих ландшафтів користувалася попитом серед кінематографістів. На території села Райгород проходили зйомки, досить відомих за радянських часів художніх фільмів: «Червоні погони» (1980р.), «Женихи» (1985p.), «Вершники» (1972р.) та «Поїзди Революції» (1979р.).

Важливе значення для відпочинку та оздоровлення відіграють ліси. Крім естетичних якостей, ліс виконує, також, оздоровчі та санітарно-гігієнічні функції. На Вінниччині поширені лісостепові ландшафти. Близько $30 \%$ території вкрито лісами. Загальна площа лісонасаджень ОТГ становить близько 416 га. Переважають ліси 3 монокультурами хвойних та широколистяних порід. Основними породами дерев є граб, дуб, ясен, клен, береза, липа та сосна. Ліси багаті ягодами та грибами. Трав'яниста рослинність характеризується великою різноманітністю. Лише диких рослин нараховується біля 500 видів, зокрема багато 3 них $є$ лікарськими. Місцями збереглися заплавні ліси 3 вільхи і тополі з домішкою ясена, верби та липи. Наявні невеликі ділянки вересових пустищ із заростями чагарників. Луги по долинах річок добре окультурені. Лісові ресурси займають важливе місце в структурі природнорекреаційного потенціалу ОТГ і можуть задовольнити різноманітні потреби рекреантів у короткочасному, довготривалому відпочинку, лікуванні та оздоровленні. Не менш різноманітна і фауна лісів: зайці, лисиці, їжаки, бобри, сарни, дикі кабани, лосі, олені. Цікавим є тваринний світ водойм та прибережних екосистем. $Є$ також тварини, які були завезені з інших географічних зон, наприклад, ондатра, нутрія, зустрічається, навіть плямистий олень.

Грунтовий покрив представлений, в основному, такими типами грунтів: ясно-сірі, сірі лісові, темносірі опідзолені. ОТГ багатана мінеральні будівельні матеріали - глину, пісок та граніт. 31984 року на території працює Самчинецьке кар'єроуправління, яке об'єднує 2 заводи в селах Райгород та Семенки, де на даний період працюють 132 робітники.

Культурно-історичні ресурси. Історія сіл, які входять до ОТГ мало відома. Перші письмові згадки датують другою половиною XVIII століття. Поблизу села Райгород знайдено залишки неолітичного поселення, біля Слобідки - давньоруське городище та поселення X-XI століть, а на території Самчинців - два слов'янські поселення XI-XII ст. нашої ери. Крім того, тут було розкопано 80 злегка заглиблених жител та господарських споруд, а також залишки залізоплавильного виробництва.

3 розвитком землеробства, ремесел і торгівлі у селах відбувалися зміни. Село Райгород мало особливе торгівельне значення і ввійшло в історію, як містечко. На території села проживало багато євреїв. Через кожні два тижні щочетверга проводився ярмарок. Він був надзвичайно великим, сюди з'їжджалися люди з багатьох районів.

За переписом населення у 1897 році в селі Райгород проживало 2240 жителів, 3 яких 995 євреїв (до нашого часу збереглося старовинне єврейське кладовище та пам'ятник жертвам Голокосту).

На території ОТГ зареєстровано релігійні общини: православна община Київського патріархату, православна община РПЦ, римокатолицька община, община ЄХБ та адвентистів сьомого дня. Серед культових споруд територіальної громади окрасою $є$ римо-католицький костел у селі Самчинці, побудований у 1909 році та церква в селі Райгород, яка була збудована в 1800 році і освячена на честь Успіня Пресвятої Богородиці. Місцева влада вважає доречним клопотання про віднесення даного храму до історичних памяток. 32019 року на території церкви жителями села проводяться реставраційні роботи.

Навчання дітей в Райгороді розпочато 31862 року, а в 1888 році відкрита церковно-приходська школа, для якої було збудовано спеціальну будівлю, яка збереглася до нашого часу.

У більшості сіл громади встановлені пам'ятники жертвам другої світової війни. 22 липня 1941 року село Райгород було окуповане німецько-фашистськими загарбниками. У тилу ворога діяли партизанські загони Володимира Волошановського та Івана Калачника. Німецькі окупанти у селі Райгород замучили і розстріляли 6 тисяч громадян - євреїв та військовополонених, багато молодих людей вивезли на роботи до Німеччини. Щебеневий завод, станцію Самчинці, Райгородську середню школу було перетворено на табори військовополонених, які тяжко працювали на заводі, добуваючи каміння і будуючи дорогу. У Райгороді залишилося 5 братських могил, три з яких - єврейські. 
Є свідчення, що в 1905-1910 роках у Райгороді французькими архітекторами було збудовано драмтеатр, але до нашого часу він не зберігся. У ньому, зокрема, виступав місцевий духовий оркестр (Rayhorod Community, 2021). У 1965 році місцевий колгосп побудував новий будинок культури, куди ж було перенесено й сільську бібліотеку. У 2019 році були проведені ремонтні роботи з відновлення та осучаснення зовнішнього вигляду Будинку культури. Він ніколи не припиняв своєї роботи i завжди підтримував духовний розвиток мешканців та їх творчу самореалізацію. На сьогоднішній день тут проводять різноманітні концерти та фестивалі різної тематики, які традиційно відвідує чи не кожен житель громади.

Соціально-економічні ресурси. Територія Райгородської ОТГ має вигідне транспортне розташування. Через центр ОТГ - с. Райгород, проходить автомагістраль державного значення M-12 (Стрий - Тернопіль - Кропивницький Знам'янка). Біля сіл Райгород та Нижча Кропивна є АЗК з реалізації нафтопродуктів.

Ще на початку 1900-х років до села почали прокладати залізничну колію, а згодом збудували станцію і депо. Залізнична станція працює i до сьогодні. Залізничне сполучення Вінниця - Зятківці, підпорядковується Жмеринській дирекції ПівденноЗахідної залізниці.

У процесі реформи децентралізації органи місцевого самоврядування здобули, насамперед, можливості щодо підвищення своєї фінансової спроможності, економічної, інвестиційної привабливості території - 3 метою якісного й комфортного проживання громадян.

Важливими бюджетоутворюючими підприємствами Райгородської ОТГ є: Філія «ЦУП» ПАТ Укрзалізниці виробничий підрозділ «Самчинецький кар'єр» 3 двома цехами: Самчинецький (с. Райгород) та Семенський (с. Семенки); пансіонат «Наш дім» (с. Нові Обиходи); завод 3 переробки молока ТОВ «Вільсон» (с. Нові Обиходи); ПП «Підвишинський». Важливу роль у розвитку економіки ОТГ відіграє мале підприємництво. На території працює чимало підприємців.

Основним природним багатством ОТГ є їі родючі землі. На території загалом нараховується 6691,94 га, сільськогосподарських угідь, у тому числі 5742,5 га ріллі.

Між власниками земельних часток (паїв) та агроформуваннями укладено договори оренди землі. У середньому ціна на оренду паю становить 2 тисячі 900 грн. за 1 га. Середня ставка орендної плати по району становить 8\% (2019р.).

Вагоме місце в економіці села завжди займав аграрний сектор. Ще в 1928 році у Райгороді було створено артіль кооперативів, які займалися переробкою продуктів садівництва, городництва та бджільництва. У 1930 році було створено колгосп. У 2021 р. на території села працювали фермери та агро-підприємці: Дядюк П., Олексієнко О., Політаєв О., Міченко В., Цилюрник О., Дідиченко В.,
Казмірчук О., Хмарук О. та ін.

У 2004 р. села Райгород, Самчинці та Нові Обиходи було газифіковано. У 2011 році було проведено капітальний ремонт приміщення Райгородської бібліотеки, яка стала переможцем міжнародного проєкту «Бібліоміст». Зараз у бібліотеці функціонує 3 комп'ютери 3 підключенням до мережі Інтернет на безкоштовній основі.

У грудні 2012 року, в приміщенні Райгородської ЗОШ відкрито дитячий садочок «Ромашка», у якому зараз виховується 36 дітей. У тому ж році в приміщенні Новообиходівської ЗОШ відкрито дошкільний навчальний заклад «Сонечко» на одну різновікову групу. Семенська сільська рада відкрила дитячий садок «Сонечко» 20 грудня 2010 року. У 2020 році зроблено ремонт ЗОШ в селі Райгород.

На території села облаштовані зони відпочинку. Найбільше таких місць облаштовано на березі річки Південний Буг, де побудовані бесідки, а поруч з ними, місця для розведення вогню, столи та лавки під відкритим небом, кладки 3 яких можна порибалити, або використовувати для стрибків у воду. Також, серед туристів може викликати зацікавленість навісний міст, який простягнувся через Річку Південний Буг та з'єднує села Райгород та Мар'янівку. Варто відмітити парк, який розташований в центрі села Райгород. У 2012 році було реставровано обеліск загиблим воїнам у Другій світовій війні. У 2018 році на території парку було облаштовано зону для відпочинку з дітьми, встановлено спортивний та дитячий майданчики.

Біля парку заходиться місцевий стадіон, на якому проводять різноманітні районні та місцеві змагання $з$ футболу та волейболу. Для зручності селян на території Райгороду та в прилеглих селах працюють поштові відділення - Укрпошти в Райгороді, Нових Обиходах, Вищій Кропивні, Семенках, а також відділення Нової пошти в селі Райгород, яке відкрилось у 2019 році. Наявність поштового зв'язку позитивно впливає на комфортне життя населення. У 2019 році було проведено кабельний інтернет Укртелеком, який дає змогу безперешкодно використовувати різноманітні технології, які працюють від мережі Інтернет. Крім того встановлено вишку мобільного зв'язку Київстар.

Частково у селах провели вуличне освітлення. В ОТГ гостро стоїть проблема утилізації побутових відходів. Як суб'єкти господарювання, так і населення громади ще не в повній мірі забезпечується організованим вивозом сміття, що призводить до виникнення стихійних звалищ. Але варто зазначити, що це питання не залишається поза увагою i, наприклад,у січні 2020 року було закуплено сміттєві баки, які призначені для сортування сміття.

У 1964 році у селі Райгород було збудовано дільничну лікарню на 40 ліжок, а в 1971 році ще й поліклініку та аптеку. В 1996 році лікарню та поліклініку районна влада намагалася закрити. Зусиллями місцевого населення вдалося залишити діючою лише поліклініку, де сьогодні працює 
денний стаціонар. $\in$ також амбулаторії у Семенках та Нових Обиходах. У селі Райгород працює 8 продуктових магазинів, а також магазини 3 продажу будівельних матеріалів та побутової хімії. $€$ перукарня та салон краси.

Туристичні дестинащії. На території ОТГ обмежена кількість туристичних атракцій, але можна здійснювати радіальні виїзди до визначних туристичних дестинацій, які знаходяться поряд, а в майбутньому є великі перспективи утворення туристичних кластерів.

Райгородська ОТГ має дуже вигідне транспортно-географічне положення, що позитивно впливає на доступність та мобільність населення. $€$ можливість прямого автотранспортного сполучення 3 обласним центром, іншими районами та містами області, а також іншими обласними центрами. Це дає можливість швидко дістатися до міст та сіл, які мають багато туристичних атракцій. Подорож територією Вінниччини приносить задоволення не тільки через красивий ландшафт, а й завдяки хорошій транспортній інфраструктурі, адже тут проходить автомагістраль, яка на сьогодні знаходиться в ідеальному стані (цим може похизуватися далеко не кожна область). Відстань від адміністративного центра ОТГ с. Райгород до столиці, обласного центру та найближчих міст така: Київ - Райгород - 303 км.; Умань - Райгород - 111км.; Вінниця -Райгород - 68 км.; Гайсин - Райгород - 21 км.; Немирів - Райгород - 27 км.

Вінницька область має високий туристичнорекреаційний потенціал, що створює значні можливості для розвитку туризму. На державному обліку перебуває 4330 пам'ятки культурної спадщини, 3 них: 1739 - археології, 1897 історії, 548 - містобудування та архітектури, 98 - монументального мистецтва, 47 - садовопаркового мистецтва, 1 - ландшафтна. Головною проблемою $\epsilon$ те, що чимало пам'яток знаходяться у занедбаному стані, вимагають реконструкції та відновлення. Більшість пам'яток знаходяться у сільській місцевості і не включені до туристичних маршрутів, а тому не задіяні в туристичному процесі. Але все ж ці пам'ятки $\epsilon$ цікавими та можуть викликати неабиякий інтерес у туристів.

У місті Немирів розташований один 3 кращих санаторно-курортних закладів нашої держави, багатопрофільний лікувальнооздоровчий та реабілітаційний заклад цілорічного функціонування - санаторій «Авангард», який має власне родовище унікальної радонової мінеральної води. Він має надзвичайно багаті традиції, адже почав працювати ще в далекому 1921 році (за декретом В. Леніна) з метою відпочинку жителів Подільської губернії і був першим в Україні. Варто зазначити, що у тогочасному Радянському Союзі існувало лише чотири подібних заклади. Санаторій мав всесоюзне значення та перебував у Республіканському підпорядкуванні, а тому тут відпочивало багато іноземців. Цікавим також $є$ те, що знаходиться санаторій у колишньому палаці графині Щербатової, який збудований за проєктом чеського архітектора Іржі Стібрала в центрі дендрологічного парку, закладеного у далекому 1787 році тодішнім власником міста Немирова графом Вінцентієм Потоцьким. Сьогодні цей санаторій з висококваліфікованими працівниками має декілька унікальних відділень, які офіційно визнані кращими в Україні.

Також, в місті є костел Йосипа Обручника (1806 p.), побудований коштом Станіслава Потоцького, церква Св. Трійці (1881р.).

Туристи, які відвідують Вінниччину, найбільше цікавляться такими дестинаціями, як Національний музей-садиба М.I. Пирогова, Державний історикокультурний заповідник «Буша», фонтан "Roshen", історична споруда водонапірна вежа, ставка Гітлера «Вервольф» та інші.

За 16 км від села Райгород знаходиться унікальна археологічна пам'ятка «Скіфські вали» - стародавне поселення, від якого залишилися оборонні насипи, які вражають своїми розмірами.

За 39 км від села Райгород знаходиться цікаве місто Тульчин, яке за результатами загальнонаціональної акції «7 чудес України» ввійшло до топ-21 історичних міст. Його найвизначнішими пам'яткамиє комплекс палацу Потоцьких (1785 p), Тульчинський технікум ветеринарної медицини (Малий або Верхній палац Потоцьких 1775 p ), краєзнавчий музей (колишній будинок Декабристів XVIII ст.), будинок Глікліха (1912 р), Успенська церква (1789 р.).

Майбутні власники садиб сільського туризму можуть орендувати, або придбати власний автотранспорт для радіальних виїздів на екскурсії до вищезгаданих туристичних дестинацій.

Отже, досліджувана ОТГ має всі передумови для розвитку сільського туризму, зокрема, вигідне суспільно-географічне положення, сприятливий клімат, чудовий ландшафт, багатий історикокультурний та туристично-рекреаційний потенціал.

Крок 2. (Право). Другий крокполягає упроведенні аналізу нормативно-правових актів, які регулюють діяльність у галузі туризму та його різновидів.

Цікаво, що вперше сутність поняття «сільський зелений туризм» розкрито у Законі України від 15 травня 2003 р. «Про особисте селянське господарство». Даний факт свідчить про важливість подальшого розвитку даного виду туризму саме на базі таких господарств. Що ж до окремих аспектів цієї підприємницької діяльності, то вони регулюються Податковим, Господарським, Цивільним та Сімейним кодексами України, а також Законами України «Про захист прав споживачів» від 12.05.1991 р., «Про туризм» від 15.09 .1995 р., «Про фермерське господарство» від 19.06.2003р., «Про сільськогосподарську дорадчу діяльність» від 17.06.2004 p., «Про державну реєстрацію юридичних осіб, фізичних осіб-підприємців та громадських формувань» від 15.05.2003 p., «Про зайнятість населення»від 05.07.2012 p., а також Постановою Кабінету Міністрів України від 15 березня 2006 p. 
№ 297 «Про затвердження порядку надання послуг 3 тимчасового розміщення (проживання)» та цілим рядом наказів, більшість яких стосується надання послуг з харчування туристів.

Законодавством України передбачено, що послуги у сфері СЗТ можуть надаватися на базі майна особистих селянських господарств. Крім того, здійснювати таку діяльність можуть особи, які ведуть фермерські господарства, отримали земельні ділянки для будівництва та обслуговування житлового будинку й господарських будівель (присадибна ділянка), а також індивідуального дачного будівництва і садівництва. До таких послуг відносять послуги 3 тимчасового розміщення (проживання) туристів, послуги 3 обслуговування житлового приміщення, харчування, послуги 3 організації дозвілля туристів тощо.

Особисте селянське господарство (ОСГ) це господарська діяльність, яка проводиться без створення юридичної особи фізичною особою індивідуально або особами, які перебувають у сімейних чи родинних відносинах і спільно проживають, з метою задоволення особистих потреб шляхом виробництва, переробки i споживання сільськогосподарської продукції, реалізації її надлишків та надання послуг 3 використанням майна такого господарства, у т. ч. й у сфері сільського зеленого туризму.

Сімейне фермерське господарство - форма підприємницької діяльності громадян - членів однієї сім'ї, які виявили бажання виробляти товарну сільськогосподарську продукцію, здійснювати ii переробку та реалізацію 3 метою отримання прибутку на земельних ділянках, наданих їм у власність, або користування, у тому числі в оренду, для ведення фермерського господарства, товарного сільськогосподарського виробництва, ОСГ (Kudla, 2015).

Власники ОСГ не виступають суб'єктами підприємницької діяльності, якщо не використовують найману працю, розміщують туристів у будинку, де живуть самі та надають послуги виключно з використанням майна свого господарства. Діяльність у сфері СЗТ, зокрема тимчасове розміщення туристів, їх харчування не підлягають ліцензуванню. Також варто зазначити, що не підлягають i сертифікації послуги, які надаються на базі майна ОСГ.

В Україні діє розроблена ГО «Спілка СЗТ України» Програма добровільної категоризації у сфері сільського зеленого туризму «Українська гостинна садиба», яка передбачає розподіл заявлених сільських садиб на чотири категорії. Цікаво, що категорії позначаються відповідними знаками та надаються терміном на три роки, а також засвідчуються сертифікатом. Знак «Українська гостинна садиба» діаметром 0,5 м надається власнику для розміщення на зовнішній стороні будинку. Оскільки власники садиб, які сертифікувалися пропонують якісніші послуги, то безперечно, сертифікація є важливим маркетинговим інструментом.
Крок 3. (Вигоди). На цьому етапі маємо оцінити суспільні вигоди розвитку сільського туризму для мешканців ОТГ.

В умовах децентралізації органи місцевого самоврядування - $\mathrm{\epsilon}$ розробниками локальної політики розвитку. Сьогодні на ОТГ покладена велика відповідальність за якісне та безпечне життя місцевого населення. Варто зазначити, що станом на 1 квартал 2021 року доходи загального фонду на одного мешканця громади складали 785,7 грн., а видатки - 1769,1 грн. Питома вага місцевих податків і зборів у доходах загального фонду 48,6\%. 27 соціальних закладів утримуються за рахунок бюджету органів місцевого самоврядування (Decentralization opens possibilities, 2021). Сьогодні, згідно вищевказаних даних, громада великою мірою залежить від державних субвенцій та дотацій. Тому дуже важливим питанням постає віднайдення перспективних напрямів розвитку, які зможуть допомогти наповнити бюджет громади.

Туризм є феноменальною сферою, яка поєднує безліч суміжних галузей економіки. В ОТГ вона залучає всіх і реально може стати драйвером їі розвитку. 3 розвитком туризму приходить популярність до місцевості. Розвиток туристичної галузі потребує відповідного розвитку транспорту, торгівлі, зв'язку, будівельної галузі, сільського господарства, a також медичного забезпечення, a отже $\epsilon$ напрямком структурної перебудови економіки.

Важливою передумовою розвитку сільського туризму має стати благоустрій сільських населених пунктів.

Хороша дорожня інфраструктура - одна 3 головних умов розвитку сільського туризму, адже яка б не була цікава туристична дестинація та до неї потрібно доїхати, а стан дорожнього покриття в сільській місцевості України у дуже поганому стані.У 2019 році траса М-12, яка проходить територією громади, потрапила до переліку пріоритетних доріг загального користування державного значення, тому було виділено кошти зі спеціального фонду державного бюджету за бюджетною програмою 3111020 «Розвиток мережі та утримання автомобільних доріг загального користування державного значення», як на проведення ремонту автомагістралі, так i на облаштування пішохідних зон, доріжок та автобусних зупинок на територіях населених пунктів відповідно до діючих норм і стандартів. Але це стосується лише центральної траси, а от вулиці села часто потребують ремонту. Більшість 3 них є грунтовими, а тому їх потрібно постійно грейдерувати та підсипати.

Також, у 2012 році Райгородська сільська рада визнана переможцем обласного конкурсу «Вода - основа життя», що дало можливість провести реконструкцію сільського водогону.

В об'єднаній територіальній громаді проводять заходи щодо забезпечення чистоти i порядку в населених пунктах громади, ліквідації несанкціонованих сміттєзвалищ, прибирання 
та приведення у належний санітарний стан прибудинкових територій, очищення від сміття парків, берегів водойм, впорядкування територій меморіальних комплексів, пам'ятних знаків, кладовищ, висаджуються дерева та квітники. План заходів по благоустрою виконують мешканці сіл, підприємств, установ, організацій, що діють на території селищної ради та представники бізнесу. Центр села Райгород потребує «родзинки», можливо, побудови фонтану, або облаштування цікавої інсталяції, біля якої могли б туристи робити фото на згадку про відвідування громади. Також було б варто на в’їзді до ОТГ поставити цікавий банер із запрошенням відвідати громаду.

Оскільки територія сприятлива для ведення сільського господарства, практично всі жителі ОТГ $є$ власниками ОСГ та мають продукти власного виробництва. Кожен п'ятий мешканець ОТГ займається вирощуванням фруктових дерев. Також $є$ тваринна ферма, де вирощують свиней, гусей та овець. Тому розвиток сільського туризму дасть можливість збувати власну продукцію, адже зараз жителі намагаються це робити влаштовуючи стихійний ринок біля автошляху.

Популярним серед жителів є розведення бджіл, що можна використовувати як додаткову послугу сільського туризму, або розвивати апітуризм, який теж вважається дуже цікавим та, безумовно, перспективним напрямом розвитку сільського зеленого туризму.

Варто відзначити, що на території ОТГ відсутні заклади харчування, зокрема, кафе та заклади розваг. Проте, якби на території був розвинений туризм, то підприємці та інвестори були б зацікавлені у будівництві відповідних закладів.

Також розвиток сільського туризму може вплинути і на вирішення такої соціально-економічної проблеми села, як розширення сфери зайнятості сільського населення, адже досить велика кількість працездатного населення, особливо жінок, їздить працювати до Росії та Польщі, що призводить до руйнування сімей місцевих мешканців. Також, великою проблемою для сіл ОТГ є високий рівень безробіття саме серед молоді, яка якраз i могла 6 розвивати сільський туризм, але, на жаль, є дещо пасивною.

Для того щоб систематизувати інформацію, а також зробити певні висновки щодо можливих проблем та перспектив розвитку сільського туризму, в Райгородській ОТГ було проведено SWOT-аналіз (табл. 1).

Таблиия 1

SWOT - аналіз розвитку сільського зеленого туризму у Райгородській ОTГ

\begin{tabular}{|c|c|}
\hline Сильні сторони & Слабкі сторони \\
\hline $\begin{array}{l}\text { 1. } \\
\text { - вигідне транспортно-географічне } \\
\text { 2. } \\
\text { 3. - переважно чисте та безпечне довкілля; } \\
\text { - ландшність мальовничих природних } \\
\text { 4. } \\
\text { 5. - сприятливі кліматичні умови; } \\
\text { 6. - багата історико-культурна спадщина регіону; } \\
\text { 7. } \\
\text { 8. - настинне населення; } \\
\text { - забезпечечь трудовиь екологічно чистими } \\
\text { продуктами, вирощеними в ОСГ }\end{array}$ & $\begin{array}{l}\text { 1. - недостатня обізнаність населення в даному } \\
\text { виді туризму; } \\
\text { 2. - відсутність досвіду в наданні послуг в сфері } \\
\text { сільського туризму; } \\
\text { 3. - низька якість умов проживання; } \\
\text { 4. - недостатньо розвинена туристична } \\
\text { інфраструктура; } \\
\text { 5. - недостатня кількість фінансової спроможності } \\
\text { для облаштування садиби; } \\
\text { 6. - відсутній бренд ОТГ }\end{array}$ \\
\hline \begin{tabular}{ll} 
& \multicolumn{1}{c}{ Можливості } \\
1. & - актуальність розвитку сільського зеленого \\
туризму через пандемію вірусу COVID-19; \\
2. & - підвищення фінансової спроможності \\
громад; \\
3. \\
- стимулювання розвитку селянських \\
господарств; \\
4. - активізація розвитку місцевої \\
інфраструктури; \\
5. - активізація місцевого ринку праці, \\
підвищення зайнятості; \\
6. - створення можливостей для повноцінного \\
змістовного відпочинку незаможної верстви \\
населення; \\
7. - збереження історико-культурних пам’яток; \\
8. - формування позитивного іміджу ОТГ; \\
9. - розвиток інформаційних технологій; \\
10. - підвищення культурного рівня й екологічної \\
свідомості мешканців села
\end{tabular} & \begin{tabular}{ll}
\multicolumn{1}{c}{ Загрози } \\
1. & - нестабільна соціально-економічна та \\
політична ситуація в країні; \\
2. \\
- недосконалість нормативно-правової бази \\
та системи правового регулювання у сфері \\
розвитку туризму; \\
3. \\
- низький рівень інфраструктури на території \\
ОТГ; \\
5. - міграція населення закордон; \\
6. - неактивність місцевих мешканців громади; \\
- правові та фінансові ризики приватних \\
7. - відсутність інвестицій; \\
8. - карантинні заборони, запроваджені через \\
пандемію вірусу СОVID-19
\end{tabular} \\
\hline
\end{tabular}


Крок 4. (Дія). На цьому кроці передбачається розробка стратегії та операційних заходів з розвитку сталого сільського туризму.

Розвиток туризму у Вінницькій області здійснюється відповідно до Програми розвитку туризму у Вінницькій області на 2021-2027 роки. Головною метою Програми визначено створення цілісної ефективної системи, яка має бути направлена на розбудову конкурентоспроможного туристичного продукту та забезпечення на цій основі комплексного розвитку територіальних громад області, зокрема їх соціально-економічного зростання за умови раціонального використання та збереження екологічної рівноваги, історикокультурної спадщини, рекреаційних ресурсів (Vinnytsia Oblast State Administration, 2021). Одним 3 найбільш популярних видів туризму, за метою подорожі, на Вінниччині є сільський зелений туризм. Також, у Програмі зазначено, що одними з найбільш активних в розвитку сільського зеленого туризму $€$ Гайсинський та Немирівський райони. Отже, перспективнимє створення кластеру 3 сільського туризму, куди зможуть долучитися i садиби досліджуваної громади.

У Плані соціально-економічного розвитку Райгородської об'єднаної територіальної громади на 2017-2020 роки було визначено головні цілі та пріоритети для стійкого економічного зростання громади. Однією 3 таких цілей визначено необхідність сприяння розвитку зеленого туризму та екотуризму. На жаль, ніяких конкретних завдань щодо реалізації даної Цілі в програмі не йдеться. У даному документі, також, знаходимо проведений аналіз інвестиційної привабливості території Райгородської ОТГ, де заявлено, що вона має достатній туристичний потенціал. Маємо надію, оскільки у місцевої влади є розуміння важливості і можливості розвитку сільського туризму в громаді, що у новому Плані його розвиток також залишиться пріоритетною метою та буде розроблено конкретні проблемні завдання. Окрім того, необхідно скласти окрему Програму розвитку сільського туризму для Райгородської сільської ради.

Дуже важливим напрямком на даному етапі $\epsilon$ пошук серед місцевого населення активних людей, які мають лідерські якості та поставлять собі за мету розвивати сільський туризм в ОТГ.

Крок 5. (Фінанси). Крок 5 полягає у визначені джерел фінансування та підтримки розвитку сільського зеленого туризму.

Інвестиції у туристичну сферу можуть бути як приватними, так і державними. Наприклад, в Свропі існують державні інструменти розвитку місцевих громад, які стимулюють залучення приватних інвестицій. Роль державного сектора полягає у підготовці стратегії місцевого розвитку. I частиною iii має бути розвиток туризму та підготовка поля дій для приватного інвестора. Завдання, як держави, так i місцевої влади полягає у створені таких умов, які були б привабливими для приватного сектора.

У Вінницькій області проводиться робота щодо залучення грантових коштів та міжнародної технічної допомоги. Вінницька районна рада та ГО «Центр регіонального розвитку» (під керівництвом Юрія Царука) виграла грант 289,8 тис. євро від Європейського Союзу на реалізацію проекту: «Туризм, як запорука динамічного соціальноекономічного розвитку сільських громад». Завдяки реалізації даного проекту проведено реставрацію зовнішньої частини палацу ГрохольськихМожайських у Вороновиці, що $є$ пам'яткою архітектури національного значення 18 століття (Vinnytsia Oblast State Administration, 2021). Крім того, створено інформаційний центр розвитку туризму, відремонтовано Жабелівський музей історії села, проведено навчальні та інформаційні заходи. У рамках грантової програми СС «Підтримка політики регіонального розвитку України» в області реалізовано проект вартістю 235,5 тис. євро «Розвиток велотуризму в Липовецькому районі». Цікавий досвід транскордонної співпраці має Ямпільський район Вінницької області та Сорокський район (Республіка Молдова). Так, 6 громад району отримали 59 тисяч євро на розвиток зеленого туризму в рамках Програми східного партнерства - «Україна-Молдова» (Vinnytsia Oblast State Administration, 2019).

Отже, участь у грантових програмах може бути гарним стартом та допомогою на первинному етапі розбудови туристичної галузі в громаді. Також, пошук інвесторів можливий через сайт Вінницької обласної державної адміністрації.

Ми провели розрахунки, яка сума необхідна для того, щоб придбати та облаштувати садибу та прилеглу територію, на прикладі, будинку в селі Райгород. Перед проведенням розрахунків ми провели онлайн-опитування власників садиб 3 різних регіонів України. Отже, власниця садиби iз Закарпаття «Котедж Маргарита» відповіла, що стартовий капітал залежить від обраного напрямку. Наприклад, якщо бізнес розпочинати 3 нуля, сума буде складати приблизно від 10000 доларів до 200000 i вище. Власник садиби на Херсонщині відповів, що можливо розпочати бізнес i без стартового капіталу, як наприклад це зробив він, маючи у власності сільський будинок батьків.

Отже, підсумуємо, що тут важливо мати бажання і можливості займатися цією справою.

Створення садиби вимагає проведення підготовчих робіт 3 облаштування території та ремонту будівлі. У селі Райгород сьогодні $\epsilon$ багато будинків, які продаються, тож придбати будинок в досить хорошому стані можна. Розрахункова вартість будинку - 250000 грн. На початковому етапі гостьові кімнати будуть створені в наявному приміщенні площею $53 \mathrm{M}^{2}$. Територія прилеглої ділянки складає 15 соток. Ремонт будівлі включить часткове перепланування і ремонт всередині, на внутрішні роботи доведеться витратити близько 300000 грн. Також, витрати в сумі близько 350000 грн підуть на зовнішні роботи. На території уже існує місце для утримання домашніх тварин. Створення привабливого дизайну території 
Таблиия 2

Розрахункова вартість облаштування закладу розміщення (сільської садиби) на 2019 р.

\begin{tabular}{|c|c|c|c|c|}
\hline № & Назва & Ціна, грн & Кількість & Ціна разом, грн \\
\hline \multicolumn{5}{|c|}{ Кімната для гостей } \\
\hline 1 & Двоспальне ліжко & 4000 & 1 & 4000 \\
\hline 2 & Односпальне ліжко & 1200 & 2 & 2400 \\
\hline 3 & Шафа-купе & 3700 & 1 & 3700 \\
\hline 4 & Приліжкова тумба & 1250 & 6 & 7500 \\
\hline 5 & Стіл письмовий & 650 & 1 & 650 \\
\hline 6 & Стілець & 750 & 10 & 7500 \\
\hline 7 & Люстра & 600 & 6 & 3600 \\
\hline 8 & Настільна лампа & 400 & 4 & 1600 \\
\hline 9 & Крісло & 1700 & 2 & 3400 \\
\hline 10 & Дзеркало & 600 & 2 & 1200 \\
\hline 11 & Телевізор & 7500 & 1 & 7500 \\
\hline \multicolumn{5}{|c|}{ Інше устаткування, сантехніка } \\
\hline 12 & Пральна машина & 8330 & 1 & 8330 \\
\hline 13 & Унітаз & 1700 & 1 & 1700 \\
\hline 14 & Душова кабіна & 4950 & 1 & 4950 \\
\hline 15 & Умивальник & 3650 & 1 & 3650 \\
\hline 16 & Дзеркало & 600 & 1 & 600 \\
\hline 17 & Стіл столовий & 3195 & 1 & 3195 \\
\hline 18 & Кухня & 6848 & 1 & 6848 \\
\hline 19 & Рушник & 175 & 16 & 2800 \\
\hline 20 & Постільна білизна & 539 & 16 & 8624 \\
\hline 21 & Покривало, подушка & 909 & 5 & 909 \\
\hline 22 & Посуд & 3752 & & 3752 \\
\hline \multicolumn{5}{|c|}{ Спортивне та туристичне спорядження } \\
\hline 23 & Велосипед дитячий & 1134 & 2 & 2268 \\
\hline 24 & Велосипед для дорослих & 3645 & 2 & 7290 \\
\hline 25 & Гамак & 400 & 4 & 1600 \\
\hline 26 & Волейбольна сітка & 699 & 1 & 699 \\
\hline 27 & М'яч волейбольний, футбольний, баскетбольний & 1290 & 3 & 1290 \\
\hline 28 & Ракетки & 171 & 3 & 513 \\
\hline 29 & Палатка & 2831 & 1 & 2831 \\
\hline 30 & Спальний мішок & 779 & 2 & 1558 \\
\hline \multicolumn{5}{|c|}{ Облаштування зони відпочинку } \\
\hline 31 & Бесідка & 5400 & 1 & 5400 \\
\hline 32 & Мангал & 440 & 1 & 440 \\
\hline 33 & Господарське приладдя & 4500 & & 4500 \\
\hline \multicolumn{4}{|c|}{ Сума } & 119343 \\
\hline
\end{tabular}

Складено авторами за поточними цінами магазинів «Jysk» та «Епіцентр» станом на 2019 рік. 
коштує близько 35000 грн. Також, важливо подбати про облаштування будинку (приблизно 119343 грн) (таблиця 2). Роботи будуть виконані власними силами.

В цілому, за нашими розрахунками, інвестиційні затрати складуть 1089343 грн (таблиця 3). Отримані результати базуються на опитувані власників сільських садиб різних регіонів та на даних отриманих в сільській раді с. Райгород.

Ми провели опитування серед населення громади, запитавши, яку суму (в гривнях), на їх думку, має складати стартовий капітал для даного виду бізнесу. Результати опитування були такими: у 43\% респондентів думка співпала 3 нашими підрахунками, це означає, що місцеві мешканці реально оцінюють потребу у фінансових ресурсах для розвитку сільського туризму.

Крок 6. (Знання).

В області успішно діє обласна громадська організація «Вінницький обласний осередок Спілки сприяння розвитку сільського зеленого туризму в Україні». Основними напрямками діяльності якої $\epsilon$ : проведення семінарів та тренінгів 3 розвитку сільського зеленого туризму та розвитку сільських територій для сільських голів, селян та спеціалістів 3 туризму, постійні консультації для членів організації щодо стандартів розвитку сільського зеленого туризму, організація спільної реклами господарів гостинних садиб, програми категоризації «Українська гостинна садиба», організація та проведення сільських фестивалів, написання соціальних проєктів 3 розвитку сільських територій до українських та міжнародних фондів.

У Вінницькій області проводять різноманітні заходи, які спрямовані на розвиток сільського туризму. Одним з осередків розвитку сільського зеленого туризму $є$ державний історикокультурний заповідник «Буша» (с. Буша, Ямпільський район), де проводять щорічні семінари. Саме в Буші 30 років тому почав розвиватися сільський туризм i сьогодні успішні практики Ямпільського району діляться власним досвідом, як можна відродити село завдяки розвитку сільського зеленого туризму. У 2019 році тут відбувся виїзний семінар «Сучасні підходи до розвитку сільського зеленого туризму» на якому відбулася презентація розвитку зеленого туризму місцевими громадами. Створено навчальний інформаційний центр Барського районного осередку спілки сприяння розвитку сільського зеленого туризму, а також тренінговий центр 3 розвитку підприємництва на селі. У районних центрах зайнятості проводяться семінари на тему: «Розвиток зеленого туризму на Поділлі».

Щоб дізнатися чи є бажання у мешканців с. Райгород отримати додаткові знання щодо розвитку сільського туризму ми провели соціологічне опитування та поспілкувалися 3 головою ОТГ Костянтином Махинею (2019 р.). Оцінивши результати опитування, ми дійшли висновку, що населення зацікавлене в отримані знань у сфері сільського зеленого туризму, оскільки було визначено, що 13\% респондентів вважають, що однією 3 найбільших перешкод для створення власного бізнесу у цій сфері $є$ відсутність навчальних центрів для підготовки населення.

Також важливо відмітити, що 50 \% респондентів відповіли, щохотіли б прослухати курс з підготовки громадян, які бажають започаткувати власну справу на селі у сфері сільського туризму 3 вивченням питань організаційно-правових та економічних засад формування та діяльності сільського туризму. Це означає, що проведення семінарів, лекцій $\epsilon$ необхідним заходом (рис. 2).

Таблиия 3

Інвестиційні затрати на заклад розміщення (с. Райгород)

\begin{tabular}{|c|l|l|}
\hline № & \multicolumn{1}{|c|}{ Нерухомість } & \multicolumn{1}{c|}{ Сума, грн. } \\
\hline $\mathbf{1}$ & Придбання будинку & 250000 \\
\hline $\mathbf{2}$ & Внутрішній та зовнішній ремонт & 685000 \\
\hline \multicolumn{2}{|c|}{ Обладнання } & 119343 \\
\hline $\mathbf{3}$ & Закупівля устаткування & \\
\hline \multicolumn{2}{|c|}{ Нематеріальні активи } & 5000 \\
\hline $\mathbf{4}$ & Реклама & 10000 \\
\hline $\mathbf{5}$ & Оформлення & \\
\hline \multicolumn{2}{|c|}{ Оборотні кошти } & 20000 \\
\hline $\mathbf{6}$ & Оборотні кошти & 1089343 \\
\hline Сума &
\end{tabular}

Складено авторами за цінами на товари та послуги станом на 2019 рік 
Результати опитування було надіслано голові об'єднаної територіальної громади с. Райгород Махині Костянтину Костянтиновичу. Управління громади наголосило, що питання сільського туризму актуальні для розвитку ОТГ та було обіцяно провести зібрання, де головною темою обговорення стане питання перспектив розвитку сільського туризму в Райгородській ОТГ, крім того буде виділено кошти, щоб запросити спеціаліста в сфері сільського зеленого туризму для проведення курсів.

Важливо відмітити туристичні компанії, які розробляють тури Вінниччиною:

- Anga-Travel - розробляє тури до Тульчина, Вінниці, Немирова;

- I GO to World - пропонує тури та екскурсії до міста Тульчин;

- Коло-Край - пропонує відпочинок в сільських садибах;

- Otpusk - пропонує відпочинок в санаторії «Авангард» м. Немирів.

Крок 7. (Бренд). 19 листопада 2019 року Вінницька ОДА провела бренд-сесію на тему «Розробка бренд-платформи «Вінниччина туристична». Було визначено, що кожна ОТГ має долучитися до створення цієї платформи, адже її цілю також є створення свого унікального бренду в кожному селі, як це сьогодні $є$ в туристичних країнах Європи. Кожна ОТГ Вінниччини має віднайти свій додатковий «туристичний магніт». У Райгородській громаді це можуть бути фестивалі. Щороку громада проводить фестиваль присвячений Дню села. На фестивалі можна скуштувати різноманітні традиційні страви, продукцію власного виробництва, відвідати святковий концерт, де виступають місцеві жителі та взяти участь у розіграші лотереї (кошти на призи, або сертифікати, які діють у якості призу, виділяють підприємці). В останні роки на фестиваль приїжджають не тільки жителі сіл об'єднаної територіальної громади, а й жителі сусідніх ОТГ. Зокрема, у 2019 році фестиваль відвідало більше

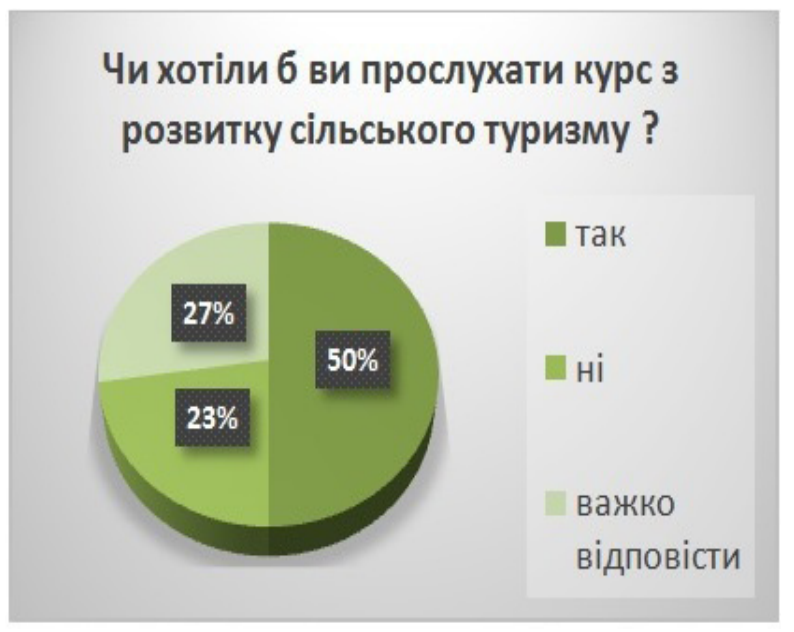

Рис. 2. Результати опитування населення щодо бажання мешканців Райгородської ОТГ отримати додаткові знання з питань розвитку сільського зеленого туризму
300 осіб. Громада має певний досвід та реальні можливості розвивати фестивальний туризм. Гарною ідеєю була б організація агрофестивалю, оскільки у громаді працює 23 агропідприємці і це люди, які мають досить активну життєву позицію. Додатковими послугами, для розвитку яких вже $\epsilon$ відповідні ресурси, можуть стати послуги іпотерапії та катання на конях, апітерапії та можливість скуштувати мед у різних господарів, майстеркласи миловаріння та свічкарства. У результаті можна задіяти багато жителів громади, оскільки послуги будуть надавати різні господарі. Також можливо проводити сезонний ягідний фестиваль, таким чином ми використаємо традиційні заняття жителів громади у туристичних цілях, що надасть можливість власникам домашньої продукції реалізовувати $\dddot{1}$ та знайти постійних клієнтів.

Важливим ресурсом у громаді є річка Південний Буг. Можна проводити змагання, наприклад, 3 рибальства, перегони на катамаранах або байдарках, щоб мінімізувати витрати, можна використовувати човни місцевих жителів, таким чином зберегти автентичність громади. Райгородська ОТГ має мальовничий ландшафт. Можна привернути увагу туристів, створивши веломаршрути різноманітної складності. Цікавим туристичним ресурсом може стати залізниця, адже вона проходить через усі села Райгородської сільської ради. Досить велику ділянку потяг їде понад річкою Південний Буг. 3 вікон потягу відкривається чудовий вид на подільські ландшафти. Зараз залізниця мало використовується, тому можна організовувати цікаві прогулянки потягом чи іншими видами залізничного транспорту. Тури поїздом - це подвійна вигода для відпочинку та подорожей, оскільки поїзд на сьогодні $є$ найбезпечнішим транспортом, і в той же час, порівняно дешевим. Для відповідних турів можна використовувати, наприклад старі паровози, щоб тур був не тільки пізнавального характеру, а й мав певну історичну цінність.

Також важливе місце у створені бренду займає туристичне ознакування та візуальна ідентифікація.

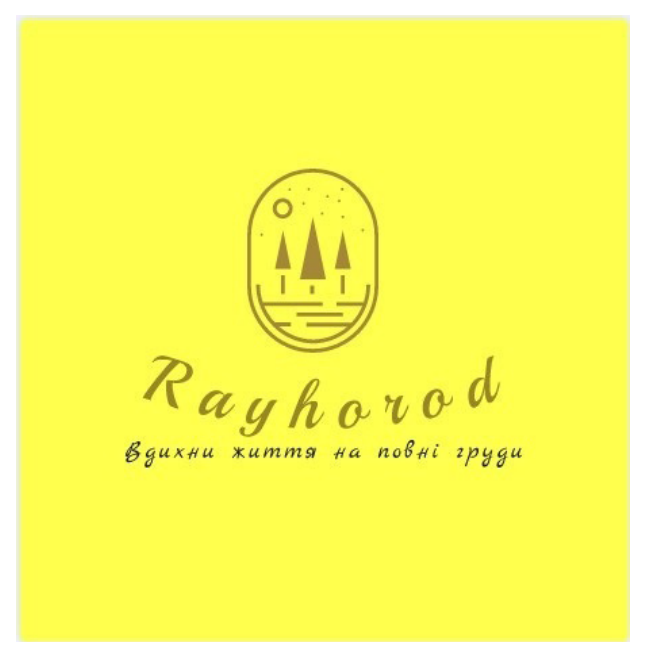

Рис. 3. Приклад логотипу для центру Райгородської ОТГ - с.Райгород (автор Світлана Міченко) 
По-перше, це створення комплексного рішення щодо єдиного стилю візуальної ідентифікації регіону 3 акцентом на туристів. По-друге, це розміщення інформаційних стендів та вказівників. По-третє, це розміщення «вірусних» об'єктів - знаків для туристів.

Досліджувана ОТГ на сьогодні немає свого логотипу та рекламного слогану. Для прикладу ми створили логотип для центру ОТГ села Райгород (рис. 3). Рекламним слоганом може бути фраза «Вдихни життя на повні груди!». Відчуття, які громада буде намагатися викликати у туристів - це свіжість, комфорт, енергію та релакс.

Логотип - це важливий елемент бренду, але це ще не бренд. На думку президента національної туристичної організації України Івана Ліптуги, «бренд не можна нав'язати зверху... Це мають зробити самі жителі, тобто носії бренду: люди, які тут працюють, живуть, бачать свою територію, розуміють, хто їхній клієнт сьогодні...» (Diadiuk, 2019). Керуючись цим принципом у нашому дослідження варіант логотипу та слоган розробила корінна жителька села Райгород - Світлана Міченко.

Дуже важливим є використання сучасних методів просування туристичного продукту в інформаційному просторі. У 2019 році створено сторінку у Фейсбук, що позитивно впливає на популярність досліджуваної ОТГ. Також, є власний ютуб-канал, де публікується інформація про проведені заходи та важливі події. Але для просування туристичного продукту варто створити туристичний портал та популяризувати туристичну привабливість в Інтернеті використовуючи, наприклад, туристичні портали України.

Крок 8. Партнерство. За великим рахунком туризм - це бізнес. Але приклад багатьох європейських країн, які успішно розвивають туризм показує, що саме злагоджена співпраця держави i приватного сектору $є$ запорукою успіху. Держава та місцеві органи влади мають фінансувати промоцію і розвиток своїх територій. Лише консолідація та координація діяльності місцевих органів влади, суб'єктів туристичного сектору, наукових установ, навчальних закладів та залучення громадськості дасть можливість забезпечити сталий розвиток туризму в громадах. Варто зазначити, що налагодження співпраці 3 територіальними громадами області в напрямку спільної діяльності щодо розвитку «зеленого туризму» $\epsilon$ однією 3 цілей довгострокової Програми розвитку туризму у Вінницькій області на 2021 - 2027 роки.

Об'єднані територіальні громади повинні вирішувати ряд завдань, 3 якими складно впоратися самостійно. До таких проблем відносяться - збір, утилізація та переробка сміття, ремонт та прибирання доріг,забезпечення якісного централізованого водопостачання та водовідведення, організація пасажирських перевезень, тощо. Для вирішення таких питань розроблено механізм міжмуніципальної консолідації (Закон «Про співробітництво територіальних громад» 2014 р.), який передбачає для вирішення існуючих проблем власного розвитку об'єднання громад на договірній основі.

Варто відмітити можливість співпраці Райгородської ОТГ, наприклад, 3 найближчою до неї Немирівською ОТГ - громадою з великим потенціалом в адміністративній, економічній, культурній, освітянській та оздоровчій сферах. Політика місцевої влади направлена на розвиток громади та залучення інвестицій, що позитивно може вплинути і на залучення інвестицій для Райгородської ОТГ. Крім того Райгородська ОТГ довгий час відносилася до Немирівського району, а тому має досить сформовані соціальноекономічні зв'язки.

Також, важливою громадою, яка розташована неподалік від Райгородської ОТГ, є Тульчинська об'єднана територіальна громада, що направляє всі зусилля на розвиток туризму. Оскільки вона багата на історико-культурні ресурси, там створено сім туристичних маршрутів, що об'єднують населені пункти громади. Щороку в громаді проводять фестиваль під відкритим небом “OPERAFESTTULCHYN”, який у 2019 році відвідало 68 тисяч глядачів - прихильників опери не тільки з України, але й із зарубіжжя. Крім того, в ОТГ добре розвинена туристична інфраструктура. Співпраця 3 Тульчинською ОТГ буде спрямована на отримання туристичного досвіду та в майбутньому, можливо, утворення туристичного кластеру.

Висновки. Як показує досвід європейських країн, важливим інструментом для порятунку сільських населених пунктів від зникнення $€$ розвиток сільського зеленого туризму. Через пандемію, спричинену COVID-19, відбувається переорієнтація туристичного ринку, зростає попит на внутрішній туризм і це певний шанс для ОТГ розвивати свої території, створюючи локальний туристичний продукт. Конкретні кроки, як розпочати довгострокову туристичну діяльність в ОТГ запропонувала громадська організація Спілка сільського зеленого туризму України. Взявши їх за основу ми спробували розробити конкретну дорожню карту розвитку сільського зеленого туризму для центра Райгородської ОТГ Гайсинського району Вінницької області - села Райгород. У процесі дослідження було з'ясовано, що для розвитку даного виду туризму в досліджуваному селі є всі передумови, а головно, люди, які хотіли б цим займатися. Тому є великі сподівання, що у наступному Плані соціальноекономічного розвитку села буде не тільки декларація можливості розбудови сільського зеленого туризму, а й передбачені конкретні кроки для реалізації цього перспективного задуму. 


\section{References:}

Barna, M., Bogush, M., \& Voloshinsky, O. (2019). Organization of Entrepreneurial Activity in the Field of Rural Tourism for Persons with Disabilities. Lviv: Rastr-7. [In Ukrainian]. [Барна М., Богуш М., Волошинський О. Організація підприємницької діяльності в сфері сільського туризму особами 3 інвалідністю: посібник. Львів : Растр-7, 2019. 206 c.]

Decentralization opens possibilities (2021). Rayhorod territorial community. Access mode: https://decentralization. gov.ua/newgromada/2036 [In Ukrainian]. [Райгородська територіальна громада / Веб-портал «Децентралізація дає можливості». Режим доступу: https://decentralization.gov.ua/newgromada/2036]

Diadiuk, K. It all starts with tourism. Vezha: Vinnytsia News Portal. Access mode: https://vezha.ua/vse-pochynayetsya-z-turyzmu-na-vinnychchyni-pochaly-rozroblyaty-brend-oblasti-foto/ [In Ukrainian]. [Дядюк К. Все починається 3 туризму. Вежа: Вінницький інформаційний портал. Режим доступу: https://vezha.ua/vse-pochynayetsya-z-turyzmuna-vinnychchyni-pochaly-rozroblyaty-brend-oblasti-foto/]

Feldman, O. (2018). Tourism as a Driver of United Territorial Community Development. Access mode: https://www. slideshare.net/olFeldman/ss-125787948 [In Ukrainian]. [Фельдман О. Туризм - як драйвер розвитку ОТГ. Режим доступу: https://www.slideshare.net/olFeldman/ss-125787948]

Gaponenko, G., Parfinenko, A., \& Shamara, I. (2019). Rural Green Tourism. Sumy: Universytetska Knyha. [In Ukrainian]. [Гапоненко Г. І., Парфіненко А. Ю., Шамара I. М. Сільський зелений туризм: навчальний посібник. Суми: ПФ «Видавництво «Університетська книга»». 2019. 178 с.]

Gorishevsky, P., Vasiliev, V. \& Zinko, Y. (2003). Rural Green Tourism: the Organization of Hospitality Services. Ivano-Frankivsk: Misto HB. [In Ukrainian]. [Горішевський П., Васильєв В., Зінько Ю. Сільський зелений туризм: організація надання послуг гостинності. Івано-Франківськ: Місто НВ, 2003. 148 с.]

Koval, O. (2019). Five steps for the development of tourism in the community. National Platform for Small and Medium Business. Access mode: https://platforma-msb.org/p-yat-krokiv-dlya-rozvytku-turyzmu-v-gromadi/ [In Ukrainian]. [Коваль О. П'ять кроків для розвитку туризму в громаді. Національна платформа малого та середнього бізнесу. Режим доступу: https://platforma-msb.org/p-yat-krokiv-dlya-rozvytku-turyzmu-v-gromadi/].

Kudla, N. (2015). Rural Tourism: Basics of Entrepreneurship and Hospitality. Kyiv: Centre for Educational Literature, 2015. [In Ukrainian]. [Кудла Н. Сільський туризм: основи підприємництва та гостинності: навчальний посіб. К.: «Центр учбової літератури», 2015. 152 с.]

Luzhanskaya, T., Makhlynets, S., \& Teblyashkina, L. (2008). Rural Tourism: History, Present and Prospects. Kyiv: Kondor. [In Ukrainian]. [Лужанська Т. Ю., Махлинець С. С., Тебляшкіна Л. І. Сільський туризм: історія, сьогодення та перспективи: Навчальний посібник / За редакцією д.г.н. професора Волошина I. М. К.: Кондор, 2008. 385 с.]

Rayhorod Community (2017). On approval of the plan of socio-economic development of the Rayhorod united territorial community for 2017-2020. Access mode: https://raygorod-otg.gov.ua/plan-socialnoekonomichnogo-rozvitkurajgorodskoi-otg-08-34-35-02-02-2018/ [In Ukrainian]. [Про затвердження плану соціально-економічного розвитку Райгородської об’єднаної територіальної громади на 2017-2020 роки. Веб-портал Райгородської ОТГ. Режим доступу: https://raygorod-otg.gov.ua/plan-socialnoekonomichnogo-rozvitku-rajgorodskoi-otg-08-34-35-02-02-2018/]

Rayhorod Community (2021). History of the village of Rayhorod. Access mode: https://raygorod-otg.gov.ua/ rajgorod-13-32-49-25-01-2017/ [In Ukrainian]. [Історія села Райгород. Веб-портал Райгородської ОТГ. Режим доступу: https://raygorod-otg.gov.ua/rajgorod-13-32-49-25-01-2017/]

Rutinsky, M. \& Zinko, Y. (2008). Green Tourism. Kyiv: Znannia. [In Ukrainian]. [Рутинський М. Й., Зінько Ю. В. Зелений туризм. К.: Знання, 2008. 271 с.]

Skrypnyk, V. (2017). Palace in Voronovytsia. vn.20minut.ua Access mode: https://vn.20minut.ua/Podii/palats-uvoronovitsi-300-tisyach-evro-na-remont-i-spogadi-pro-ogolenih-10615680.html [In Ukrainian]. [Скрипник В. Палац у Вороновиці. Веб-портал vn.20minut.ua. Режим доступу: https://vn.20minut.ua/Podii/palats-u-voronovitsi-300-tisyach-evro-na-remont-i-spogadi-pro-ogolenih-10615680.html]

Ukrainian Union of Rural Green Tourism (2021). Access mode: https:/www.greentour.com.ua [In Ukrainian]. [Спілка сільського зеленого туризму України. Режим доступу: https:/www.greentour.com.ua]

Vasyliyev, V. (ed.). (2018). Rural Green Tourism - From Separated Estates to Territorial Clusters. Kyiv: Union of Rural Green Tourism of Ukraine. [In Ukrainian]. [Сільський зелений туризм - від роз'єднаних садиб до територіальних кластерів / ГО «Спілка сільського зеленого туризму України» / під ред. В. Васильєва. К. 60 с.].

Vihrov, M. (2018). Ukrainian village: extinction or evolution. Ukrainian Week. September 17, 2018. Access mode: https://tyzhden.ua/Society/219622 [In Ukrainian]. [Віхров М. Українське село: вимирання чи еволюція. Український тиждень. 17 вересня 2018 р. Режим доступу: https://tyzhden.ua/Society/219622

Vinnytsia Oblast State Administration (2019). Green tourism in the Yampil district: we are surprised by what we have. Access mode: http:/www.vin.gov.ua/news/ostanni-novyny/20874-zelenyi-turyzm-na-yampilshchyni-my-dyvuiemo-tym-shcho-v-nas-ie [In Ukrainian]. [Зелений туризм на Ямпільщині: ми дивуємо тим, що в нас є / Вінницька обласна державна адміністрація. Режим доступу: http://www.vin.gov.ua/news/ostanni-novyny/20874-zelenyi-turyzmna-yampilshchyni-my-dyvuiemo-tym-shcho-v-nas-ie]

Vinnytsia Oblast State Administration (2021). Tourism development program in Vinnytsia region for 2021 - 2027. Access mode: http://www.vin.gov.ua/images/doc/vin/ODA/ogoloshenia/programa-turizm2020.pdf [In Ukrainian]. [Програма розвитку туризму у Вінницькій області на 2021 - 2027роки / Вінницька обласна державна адміністрація. Режим доступу: http://www.vin.gov.ua/images/doc/vin/ODA/ogoloshenia/programa-turizm2020.pdf] 